\title{
Democratic Innovation in Transnational and Global Governance
}

\author{
Rask, Mikko Tapani
}

Edward Elgar

2019

Rask, M T , Bedsted , B , Andersson , E \& Kallio , L H 2019 , Democratic Innovation in Transnational and Global Governance . in S Elstub \& O Escobar (eds), The Handbook of Democratic Innovation and Governance ., 24 , Edward Elgar , Cheltenham , pp. 354-369 .

http://hdl.handle.net/10138/318201

cc_by_nc_nd

acceptedVersion

Downloaded from Helda, University of Helsinki institutional repository.

This is an electronic reprint of the original article.

This reprint may differ from the original in pagination and typographic detail.

Please cite the original version. 


\title{
Democratic Innovation in Transnational and Global Governance
}

\author{
Mikko Rask ${ }^{1}$, Bjørn Bedsted ${ }^{2}$ Edward Andersson $^{3}$ and Liisa Kallio ${ }^{4}$
}

In: Elstub, S. and Escobar, O. (2019). Handbook of Democratic Innovation and Governance. Edward Elgar Publishing. Cheltenham, UK and Northampton, MA, USA: Edward Elgar.

\begin{abstract}
Abstact
This chapter focuses on the democratic innovations of deliberative mini-publics by exploring the ways in which they can contribute to the democratisation of transnational and global governance. As international institutions like the European Union and global frameworks such as the Paris Climate Agreement are suffering a crisis of legitimacy, there is a need to further develop transnational democracy. This chapter provides the first systematic mapping of transnational mini-publics in the context of transnational and global governance. Data includes 19 mini-publics that are catalogued and analysed. Emerging trends include high participant learning, low direct policy, and moderate institutional and media impacts. The prospects, challenges and emerging research needs are discussed as well. ICTs, online methods and Artificial Intelligence will likely add new opportunities and lower the expenses of global deliberative mini-publics in the future.
\end{abstract}

\section{Key words:}

democratic innovation, transnational, global, governance, mini-publics 


\section{$<b>1$. Introduction ${ }^{5}$}

As the global interconnectedness between national economies has increased, so has the complexity of addressing societal challenges and consequently, more policy making has become transnational or global in scale. Transnational and global governance bodies, such as the United Nations (UN), European Union (EU), World Trade Organization (WTO), Group of Twenty (G20), and the World Bank have aimed to coordinate policy making in different fields. This has led to growing concerns about the lack of democratic legitimacy, much related to the gap between policy makers and the citizens affected by the decisions they make at the international level. This article focuses on the democratic innovations of deliberative mini-publics, and discusses the ways in which they can contribute to the democratisation of transnational and global governance. Democratic innovations have been slow to spread to international politics, and global referenda or transnational participatory budgeting processes are yet to be seen. Deliberative mini-publics, however, have seen use in international setting. The potential and limitations of deliberative democratic processes (DDPs) more generally also apply at the international level (for the definitions and characteristics of minipublics as a type of democratic innovation, see Chapter 3 in this Handbook; Einsiedel et al., 2001; Goodin and Dryzek, 2006; Grönlund et al. 2014; Kahane et al., 2013). Before entering the arena of transnational and global governance, mini-publics have been tested and applied in local, regional, and national contexts for several decades.

The history of transnational deliberative mini-publics is short. It begins in the middle of 2000s. The RAISE project in the year 2005 is probably the first transnational arrangement, where lay citizens from several countries were assembled to deliberate international policy issues under an approach that can be characterised as a 'mini-public' (Boucher 2009; Boussaguet and Dehousse, 2008). RAISE was inspired by the consensus conference approach and it convened a citizen jury of 26 citizens from the EU member states to deliberate about new regional and urban sustainability approaches in Europe. This project was soon followed by Meeting of Minds, a citizen deliberation on brain science. It also applied the consensus conference approach and assembled national panels of 14 citizens in nine countries, 126 participants in total (Boucher 2009; Goldschmidt and Renn, 2006). Since then, the field of transnational citizen deliberations has developed rapidly. For example, World Wide Views on Climate and Energy that was organised a decade later in 2015, as the third global citizen consultation in history, involved nearly 10,000 citizens in 76 countries. It used a novel hybrid method called World Wide Views (WWViews) that was designed as a low-cost process to assemble panels of 100 citizens simultaneously in many countries to deliberate about transnational policy issues. In total, some two dozen transnational mini-public processes have been run by different organsisations and networks, using different methods and approaches.

\section{$<c>1.1$ The journey of mini-publics}

The journey of mini-publics started in the late 1960s and early 1970s when, as part of an overall movement in Western societies towards further democratisation, many new approaches and models of citizen participation in policy making were introduced (see Chapters 19 and 21 in this Handbook).

The first mini-publics were used at the local or national scale (Voß and Amelung, 2016). Among the first experiments were planning cells in Germany, citizen juries in the U.S. and consensus conferences in Denmark (Grönlund et al, 2014; Asselt Rijkens-Klomp, 2002; Geurts and Mayer, 1996; Jungk and Muellert, 1987).

A second, inter-local and increasingly international ${ }^{6}$ phase emerged in the beginning of 1990 s, as practitioners started to exchange experiences and collaborate more extensively (Voß and Amelung, 2016). A third, trans-local and transnational phase was initiated in the beginning of the 2000s, along with the first international mini-public processes and emergence of trans-local centers of expertise (Voß and Amelung, 2016). Even though the development of transnational mini-publics has been dominated in recent years by Europeans, some of the early methods were imported from the U.S. (see Chapter 25 in this Handbook) where deliberative mini-publics have been institutionalised for several decades with support from prominent 
institutions including Jefferson Centre, America Speaks, National Council for Dialogue and Deliberation, Center for Deliberative Democracy, and Expert and Citizen Assessment of Science and Technology network (ECAST). In Europe (Chapter 27), The European Commission (EC) has played a crucial role, particularly through its science-in-society funding schemes (Kies and Nanz, 2013).

\subsection{Critical reflections}

As methods for mini-public deliberations began to proliferate and travel across national borders, discussions followed about the right match between a given methodology and the political and cultural context. A key discussion has been whether the democratic rationale behind methods, such as the consensus conference, developed in Denmark, would be too alien to other countries such as India, Japan, and even France (e.g., Einsiedel et al, 2001; Rask and Worthington, 2015). Another discussion has been the extent to which the method itself could introduce a certain bias and framing of the policy issues to be deliberated - or 'political performativity', instead of neutrality (e.g., Voß and Amelung, 2016; Felt and Fochler, 2010; Irwin 2001; Levidow, 1998). Yet another issue of critical reflection is how, in different and sometimes competing ways, mini-publics vs. non-governmental organisations (NGOs) can claim to represent the values and interests of the civil society (e.g., Amelung and Baumgarten, 2017; Rask and Worthington, 2012). What has made a critical and objective analysis of these issues challenging, is that both researchers, practitioners and inventors tend to have a slight bias toward focusing on best practices rather than on problems and failures (Spada et al., 2017). Reflection of these and other critical issues is, however, important in order to keep the development of transnational deliberation methodologies open and dynamic. First and most importantly, mini-publics can potentially help to bridge the 'democracy gap' in international politics that emerges while more and more policies are coordinated beyond the individual state but where the global demos who have to bear the consequences of such policies has less and less democratic control in them (Dryzek, 2016; Dryzek and Stevenson, 2011; Klinke, 2009). Second, trademarks and other efforts to protect methodological creations can be seen in two ways: as serving organisational interests, where financial stakes play a role in the development of new deliberative tools, ${ }^{7}$ or they can also be seen as a way to ensure high level of integrity and trustworthiness of such tools. Furthermore, open competition prevails between alternative designs and there are no particular limitations for new initiatives to emerge into the market (Worthington et al., 2012).

\section{$<c>1.3$ Toward expressions and practices of global citizenship}

The question of global citizenship, or citizenship beyond nationality, is among the core issue of transnational and global deliberations. Historically, the sense of citizenship has emerged from common values, religions and experiences shared by communities of interest or as citizens of states, as well as from external forces, such as the threats of neighboring communities, or natural disasters that imperil daily subsistence (Blue et al. 2012; Young 1989). Despite the rise of global threats, such as nuclear proliferation, biodiversity loss or global warming, expressions of global citizenship have remained largely unarticulated. This reflects the simple fact that for most people, everyday concerns remain locally based, both institutionally and perceptually, while trans-boundary issues seem remote despite their transmission into homes worldwide by television and the Internet (Worthington and Egelhoff, 2015).

This is exactly the area, where deliberative democratic innovations have the largest potential. Despite some daunting challenges, transnational and global mini-publics can indeed provide a new kind of space for articulating public concerns on critical problems of our era, and opportunity for citizens to influence international policy processes. Such opportunities can increase people's sense of ownership of decisions at the international level, and in so doing, revitalise and develop the practice of democracy.

The potential of public participation for the democratisation of international politics has been largely recognised and supported by several pieces of regulation of international agencies, such as the EC (2001) and OECD (2001). The Aarhus Convention (2001) that commits European governments to ensure public 
participation and access to information in all environmental policy making, is another important piece of regulation (Dietz and Stern, 2008). More recent examples of international policies, include, the EU's policy of Responsible Research and Innovation (RRI) ${ }^{8}$ that defines 'public engagement' as one of its key pillars, and is very explicit about the fact that the term 'public' entails both 'citizen' and 'stakeholder' engagement. At the UN level, things are less clear. Although the Principle 10 of the Rio Declaration, from 1992, makes explicit reference to the participation of 'citizens', this explicit reference to 'citizen' participation has been squeezed out of subsequent conventions and is not included in the Sustainable Development Goals. The Conventions on Climate Change and Biodiversity do call for 'public' participation, but this has predominantly been interpreted to mean the participation of different stakeholders, interests, and minority groups, rather than 'citizen' participation as such (cf., Worthington and Egelhoff, 2015).

While international regulations have partly supported the journey of transnational mini-publics, the journey itself has been far from linear. There are many factors that explain this. Among supportive factors, in addition to the international regulations just mentioned, is the increasing capacity of international professional networks to carry out large-scale deliberations, involving an increasing number of countries. Hindering factors include, economic downturns and the difficulty of identifying suitable funding. Another potential obstacle is the current re-emergence of authoritarian populist models of policy making in various parts of the world, which places little value in the egalitarian and deliberative spirit of mini-publics. Finally, considerable complications are related to the negotiation and interpretation of the appropriate role of mini-publics in providing political representation in international policy processes. In some cases mini-publics have been perceived as reducing the power of civil society organisations (CSOs) in representing society, which has understandably caused concern among such groups (Rask et al., 2012). As studies on the adaptation of WWViews in several countries suggest (Rask et al., 2012b; Rask and Worthington, 2015), many of the local partners have struggled to 'sell' the mini-public concept to local policy actors, who are more accustomed to opinion polls and focus groups as proxies of public opinion. Another complication is how to fit globally coordinated mini-publics to local contexts and 'civic epistemologies', or culturally entrenched assumptions of authoritative knowledge (Jasanoff, 2005).

In the remainder of this chapter, we will provide an overview of the democratic innovations of deliberative mini-publics in the context of transnational and global governance. We will do this, in Section two, by cataloguing and analysing the characteristics of 19 transnational mini-publics identified through an international mapping exercise. In Section three, we will make observations on some emerging trends and impacts in this field. In the final section, we will discuss the prospects, challenges and emerging research needs.

\section{$<b>2$. Characteristics of transnational and global mini-publics}

In order to analyse the characteristics of transnational and global mini-publics, we created a sample of cases identified by reviewing recent research literature and relying on our own access to such processes in Europe. We do not claim that the list is exhaustive, but it covers a large body of recent activity in Europe and beyond. While collecting the data, we consulted project websites, Participedia, academic literature, process evaluations (for example Brandstetter et al., 2011; Toulemonde et al. 2009; Goldschmidt et al., 2008; Goldschmidt and Renn, 2006), and some previous comparisons (Kies and Nanz 2013; Sclove 2010; Boucher; 2009, and Boussaguet and Dehousse, 2008).

Table 1 Transnational \& global mini-publics (for additional information, see the NOTES below) 


\begin{tabular}{|c|c|c|c|c|c|c|c|}
\hline CASE & YEAR & METHOD & TOPICS & COORDINATOR & $\begin{array}{l}\text { PART- } \\
\text { ICIP- } \\
\text { ANTS }\end{array}$ & SCOPE & $\begin{array}{l}\text { BUDG } \\
\text { ET } \\
\$ 1,000 \\
s\end{array}$ \\
\hline $\begin{array}{l}\text { Case } 19 \text { Citizen } \\
\text { \& Multi-Actor } \\
\text { Consultation on } \\
\text { Horizon } 2020 \\
\text { (CIMULACT) }\end{array}$ & $\begin{array}{l}\text { On- } \\
\text { going }\end{array}$ & $\begin{array}{l}\text { Inspired by } \\
\text { CIVISTI }\end{array}$ & $\begin{array}{l}\text { Visions for } \\
\text { desirable \& } \\
\text { sustainable } \\
\text { futures }\end{array}$ & DBT & 1000 & $\begin{array}{l}\text { EU } 30 \\
\text { countries }\end{array}$ & $\begin{array}{l}\$ 4134 \\
*\end{array}$ \\
\hline $\begin{array}{l}\text { Case } 18 \text { Action } \\
\text { plan on Science } \\
\text { in Society } \\
\text { related issues in } \\
\text { Epidemics and } \\
\text { Total pandemics } \\
\text { (ASSET) }\end{array}$ & 2017 & $\begin{array}{l}\text { Inspired by } \\
\text { WWViews }\end{array}$ & Health & $\begin{array}{l}\text { ISS coordinated } \\
\text { the project \& } \\
\text { DBT } \\
\text { coordinated the } \\
\text { citizen } \\
\text { participation } \\
\text { process }\end{array}$ & 400 & $\begin{array}{l}\text { EU } 8 \\
\text { countries }\end{array}$ & $\$ 576$ \\
\hline $\begin{array}{l}\text { Case } 17 \text { Public } \\
\text { Participation in } \\
\text { Developing a } \\
\text { Common } \\
\text { Framework for } \\
\text { Assessment \& } \\
\text { Management of } \\
\text { Sustainable } \\
\text { Innovation } \\
\text { (CASI) }\end{array}$ & 2017 & CIVISTI & $\begin{array}{l}\text { Climate } \\
\text { action, } \\
\text { resource } \\
\text { efficiency \& } \\
\text { raw } \\
\text { materials }\end{array}$ & $\begin{array}{l}\text { ARC Fund } \\
\text { coordinated the } \\
\text { project \& DBT } \\
\text { coordinated the } \\
\text { citizen } \\
\text { participation } \\
\text { process }\end{array}$ & 245 & $\begin{array}{l}\text { EU } 12 \\
\text { countries }\end{array}$ & $\$ 400$ \\
\hline $\begin{array}{l}\text { Case } 16 \\
\text { Citizens' debate } \\
\text { on space for } \\
\text { Europe }\end{array}$ & 2016 & $\begin{array}{l}\text { Inspired by } \\
\text { WWViews }\end{array}$ & $\begin{array}{l}\text { Space } \\
\text { exploration } \\
\text { \& space } \\
\text { science }\end{array}$ & $\begin{array}{l}\text { ESA, MP, nexus } \\
\text { \& ISINNOVA }\end{array}$ & 2000 & $\begin{array}{l}\text { EU } 22 \\
\text { countries }\end{array}$ & $\begin{array}{l}\text { Not } \\
\text { public }\end{array}$ \\
\hline $\begin{array}{l}\text { Case } 15 \text { World } \\
\text { Wide Views on } \\
\text { Climate \& } \\
\text { Energy }\end{array}$ & 2015 & WWViews & $\begin{array}{l}\text { Climate \& } \\
\text { Energy }\end{array}$ & $\begin{array}{l}\text { DBT, MP, CNDP } \\
\& \text { UNFCCC }\end{array}$ & 8700 & $\begin{array}{l}\text { Global } 76 \\
\text { countries }\end{array}$ & $\$ 2050$ \\
\hline $\begin{array}{l}\text { Case } 14 \text { Europe } \\
\text { Wide Views on } \\
\text { Sustainable } \\
\text { Consumption } \\
\text { (part of PACITA) }\end{array}$ & 2014 & WWViews & $\begin{array}{l}\text { Sustainable } \\
\text { consumptio } \\
n\end{array}$ & DBT & 1000 & $\begin{array}{l}\text { EU } 11 \\
\text { countries }\end{array}$ & $\begin{array}{l}\$ 1027 \\
*\end{array}$ \\
\hline $\begin{array}{l}\text { Case } 13 \text { Views, } \\
\text { Opinions \& } \\
\text { Ideas of Citizens } \\
\text { in Europe on } \\
\text { Science } \\
\text { (VOICES) }\end{array}$ & 2014 & $\begin{array}{l}\text { Focus } \\
\text { groups }\end{array}$ & $\begin{array}{l}\text { Urban } \\
\text { waste as a } \\
\text { resource }\end{array}$ & Ecsite & 1000 & $\begin{array}{l}\text { EU } 27 \\
\text { countries }\end{array}$ & $\begin{array}{l}\$ 2216 \\
*\end{array}$ \\
\hline
\end{tabular}




\begin{tabular}{|c|c|c|c|c|c|c|c|}
\hline $\begin{array}{l}\text { Case } 12 \text { World } \\
\text { Wide Views on } \\
\text { Biodiversity }\end{array}$ & 2012 & WWViews & Biodiversity & $\begin{array}{l}\text { DBT, UNCBD, } \\
\text { The Danish } \\
\text { Ministry of the } \\
\text { Environment }\end{array}$ & 3000 & $\begin{array}{l}\text { Global } 25 \\
\text { countries }\end{array}$ & $\$ 3000$ \\
\hline $\begin{array}{l}\text { Case } \mathbf{1 1} \\
\text { Sustainable } \\
\text { water } \\
\text { management } \\
\text { connecting } \\
\text { research, } \\
\text { people \& policy } \\
\text { makers in } \\
\text { Europe } \\
\text { (AWARE) }\end{array}$ & 2011 & $\begin{array}{l}\text { Citizens } \\
\text { conference } \\
\text { processes } \\
\text { (European } \\
\text { \& local) }\end{array}$ & $\begin{array}{l}\text { Quality of } \\
\text { coastal } \\
\text { waters }\end{array}$ & ISINNOVA \& MP & 30 & $\begin{array}{l}\text { EU } 5 \\
\text { (regional) }\end{array}$ & $\begin{array}{l}\$ 2163 \\
*\end{array}$ \\
\hline $\begin{array}{l}\text { Case } 10 \text { Citizen } \\
\text { Visions on } \\
\text { Science, } \\
\text { Technology \& } \\
\text { Innovation } \\
\text { (CIVISTI) }\end{array}$ & 2010 & CIVISTI & $\begin{array}{l}\text { New, } \\
\text { emerging } \\
\text { topics for } \\
\text { the EU R\&D } \\
\text { policy }\end{array}$ & DBT & 175 & $\begin{array}{l}\text { EU } 7 \\
\text { countries }\end{array}$ & $\begin{array}{l}\$ \\
1028^{*}\end{array}$ \\
\hline $\begin{array}{l}\text { Case } 9 \text { World } \\
\text { Wide Views on } \\
\text { Global Warming }\end{array}$ & 2009 & WWViews & $\begin{array}{l}\text { Climate } \\
\text { change }\end{array}$ & DBT & 3900 & $\begin{array}{l}\text { Global } 38 \\
\text { countries }\end{array}$ & $\$ 3500$ \\
\hline $\begin{array}{l}\text { Case } 8 \text { The } \\
\text { EuroPolis } \\
\text { Project }\end{array}$ & 2009 & $\begin{array}{l}\text { Deliberativ } \\
\text { e Polling }\end{array}$ & $\begin{array}{l}\text { Climate } \\
\text { change \& } \\
\text { immigratio } \\
\mathrm{n}\end{array}$ & $\begin{array}{l}\text { The University } \\
\text { of Siena }\end{array}$ & 348 & $\begin{array}{l}\text { EU } 27 \\
\text { countries }\end{array}$ & $\$ 3625$ \\
\hline $\begin{array}{l}\text { Case } 7 \\
\text { European } \\
\text { Citizens' } \\
\text { Consultation II }\end{array}$ & 2009 & $\begin{array}{l}\text { Inspired by } \\
21 \text { st } \\
\text { Century } \\
\text { Town } \\
\text { Meeting \& } \\
\text { World Café }\end{array}$ & $\begin{array}{l}\text { The } \\
\text { economic } \\
\& \text { social } \\
\text { future of } \\
\text { the EU }\end{array}$ & KBF & 1600 & $\begin{array}{l}\text { EU } 27 \\
\text { countries }\end{array}$ & $\$ 4555$ \\
\hline $\begin{array}{l}\text { Case } 6 \text { Raising } \\
\text { citizens' } \\
\text { awareness \& } \\
\text { appreciation of } \\
\text { EU research on } \\
\text { sustainable } \\
\text { transport in the } \\
\text { urban } \\
\text { environment }\end{array}$ & 2009 & $\begin{array}{l}\text { Citizens } \\
\text { Conference } \\
\text { Processes } \\
\text { (European } \\
\text { \& local) }\end{array}$ & $\begin{array}{l}\text { Research } \\
\text { on urban } \\
\text { transport in } \\
\text { Europe }\end{array}$ & ISINNOVA \& MP & 50 & $\begin{array}{l}\text { EU } 27 \\
\text { countries }\end{array}$ & $\begin{array}{l}\$ 1151 \\
*\end{array}$ \\
\hline $\begin{array}{l}\text { Case } 5 \\
\text { Tomorrow's } \\
\text { Europe }\end{array}$ & 2007 & $\begin{array}{l}\text { Deliberativ } \\
\text { e Polling }\end{array}$ & $\begin{array}{l}\text { Policy } \\
\text { issues } \\
\text { affecting } \\
\text { the future } \\
\text { of the EU }\end{array}$ & $\begin{array}{l}\text { Jacques Delors } \\
\text { Institute } \\
\text { (former Notre } \\
\text { Europe) }\end{array}$ & 362 & $\begin{array}{l}\text { EU } 27 \\
\text { countries }\end{array}$ & $\$ 2175$ \\
\hline
\end{tabular}




\begin{tabular}{|c|c|c|c|c|c|c|c|}
\hline $\begin{array}{l}\text { Case } 4 \\
\text { European } \\
\text { Citizens' } \\
\text { Consultation I }\end{array}$ & 2007 & $\begin{array}{l}\text { Inspired by } \\
21 \text { st } \\
\text { Century } \\
\text { Town } \\
\text { Meeting \& } \\
\text { World Café }\end{array}$ & $\begin{array}{l}\text { Future of } \\
\text { the EU }\end{array}$ & KBF & 1800 & $\begin{array}{l}\text { EU } 27 \\
\text { countries }\end{array}$ & $\$ 5510$ \\
\hline $\begin{array}{l}\text { Case } 3 \\
\text { European } \\
\text { Citizens' Panels }\end{array}$ & 2007 & $\begin{array}{l}\text { Citizens' } \\
\text { Panel }\end{array}$ & $\begin{array}{l}\text { Future of } \\
\text { rural areas } \\
\text { in Europe } \\
\end{array}$ & AEIDL \& FFG & 337 & $\begin{array}{l}\text { EU } 9 \\
\text { countries }\end{array}$ & $\$ 2320$ \\
\hline $\begin{array}{l}\text { Case } 2 \text { Meeting } \\
\text { of Minds }\end{array}$ & 2006 & $\begin{array}{l}\text { Inspired by } \\
\text { consensus } \\
\text { conference } \\
\end{array}$ & $\begin{array}{l}\text { Brain } \\
\text { science }\end{array}$ & KBF & 126 & $\begin{array}{l}\text { EU } 9 \\
\text { countries }\end{array}$ & $\$ 2600$ \\
\hline $\begin{array}{l}\text { Case } 1 \text { Raising } \\
\text { Citizens \& } \\
\text { Stakeholders' } \\
\text { Awareness \& } \\
\text { Use of New } \\
\text { Regional \& } \\
\text { Urban } \\
\text { Sustainability } \\
\text { Approaches in } \\
\text { Europe (RAISE) }\end{array}$ & 2005 & $\begin{array}{l}\text { Inspired by } \\
\text { consensus } \\
\text { conference }\end{array}$ & $\begin{array}{l}\text { Regional \& } \\
\text { urban } \\
\text { sustainabili } \\
\text { ty policies }\end{array}$ & ISINNOVA & 26 & $\begin{array}{l}\text { EU \& } \\
\text { Romania } \\
26 \\
\text { countries }\end{array}$ & $\$ 483$ \\
\hline
\end{tabular}

NOTE about COORDINATORS: Following abbreviations were used: $A E I D L=$ The European Association for Information on Local Development; $A R C$ fund = Applied Research and Communications Fund; CNDP = French National Commission for Public Debate; Ecsite = European Network of Science Centres and Museums; ESA = European Space Agency; FFG = Foundation for Future Generations; Fraunhofer ISI = Fraunhofer-Institut für System- und Innovationsforschung; ISINNOVA= Institute of Studies for the Integration of Systems; ISS= Istituto Superiore di Sanita; KBF = King Baudouin Foundation; MP = Missions Publiques; nexus = nexus Institute for Cooperation Management and Interdisciplinary Research; $P d M=$ Politecnico di Milano; SDS = Strategic Design Scenarios; UNCBD = The Secretariat of the Convention on Biological Diversity; UNFCCC = United Nations Framework Convention on Climate Change secretariat.

NOTE about BUDGETS: There are following qualifications about the way to calculate and compare the budgets. First, the budgets in Euros were converted to the exchange rate of USD, on 30th of June in the year in question. Second, we have aimed at indicating the overall budgets that were used for organszing the deliberations. In cases where the project was solely focused on arranging the deliberation, as for example in deliberative polls, indicating the budget was more straightforward. In some other cases, as for example in WWViews, we only had access to the global coordination costs, while local arrangement costs that were not available, for which reason they are excluded in the figure. (Our rough estimation for such costs is $\$ 1,2-1,6$ million for the case of WWViews on Climate and Energy, which results in an estimate of an additional 40$50 \%$ extra to the global coordination costs of WWViews.) Yet in some other cases, the project did not only include deliberations but also other research and development activities. In such cases, for example CASI, where the separate budget for the part of deliberation could be calculated, this is indicated in the figure, while for those cases where we only had access to the full budget of the project, this is indicated with an asterisks*, to remind that the figure gives an exaggerated picture of the cost of deliberation, for which reason those figures are also excluded from the following comparisons. 


\section{$<c>2.1$ Three types of cases}

All of the cases in Table 1 include features of sortition and deliberation. However, methodologically they are a mixed complication of cases, where opinions can be divided about their belonging to the class of 'pure minipublics' or something else.

Three types of projects can be discerned: i) public deliberation processes that focus mainly on the consultation of public opinions (examples: WWViews on Climate and Energy, Europolis), ii) demonstration projects that have as part of their aim to prove the applicability of specific deliberation methods at the transnational level (example: Tomorrow's Europe that applied the deliberative poll method), and iii) research, development and training projects that aim to develop new consultation methods and develop capacities in their application (examples: PACITA and CIVISTI). Many projects have aspects of all three functions.

Reflecting the increasing maturity of the field, the applicability of some of the methods has already been demonstrated, which paves way for more straightforward application of such tools, for instance, WWViews and CIVISTI. The transnational journey of deliberative poll and some other methods that were earlier used in the international context, instead, has stopped, at least for the time being.

\section{$<c>2.2$ Years and frequencies}

The year indicated in Table 1 refers to the time when the mini-public deliberations took place. The planning and execution of transnational mini-publics normally require two to three years.

The first transnational mini-public process is the RAISE project, from the year 2005. The number of mini publics peaked in 2007 when the global economy was still thriving, but dropped to zero for the following year, when the economic crisis started to emerge. The number of mini-publics peaked again in 2009 , when the financial crisis had reached its deepest pit. The financial crisis may have had an impact on the financing of mini publics, but it could only be seen with delay. The number of mini-publics has stayed fairly steady since then.

History was made in 2009, when the first global (as opposed to regional) citizen deliberation, WWViews on Global Warming was organised. The World Wide Views Alliance (WWViews Alliance) that is the professional network operating WWViews is still active and looking for new opportunities to organise global deliberations.

\section{$<c>2.3$ Methods and their origins}

A clear succession of methods can be seen from consensus conferences to $21^{\text {st }}$ Century Town Meeting and World Café inspired methods to Deliberative Polling, and finally to WWViews and CIVISTI. WWViews has established its place as the most utilised method among transnational and global mini-publics.

At a closer look, there are three main methodological pathways. First, the consensus conference model that is a small-scale mini-public, involving typically 10-20 lay citizens, has served as the reference for the two first transnational mini-publics, RAISE and The Meeting of Minds, as well as an inspiration for many other following processes.

Second, such large-scale mini-publics that have previously been applied in local or national level debates, have been directly applied at the international level (Cases 4-7). The two examples here are Deliberative polling ${ }^{\circ}$, developed by James Fishkin and Robert Luskin in the early 1990s (Grönlund et al., 2014; Fishkin, 1995; Fishkin, 2009), at The Center for Deliberative Democracy, and The 21st Century Town Meeting ${ }^{T M}$, developed by Carolyn Lukensmeyer, at the end of 1990s, for The AmericaSpeaks organisation (Lukensmeyer et al., 2005). 
The third route has been the preparation of methods tailored particularly for transnational deliberations, including, WWViews and CIVISTI. The WWViews method, for example, is a hybrid of a handful of well-tested citizen participation methods previously used at the local, national, and regional levels (Bedsted et al., 2012). Overall, methodological hybridity is a general characteristic of most cases we have looked at, including, the combination of face-to-face processes with on-line methods, and use of supportive techniques and multiple communication channels. ${ }^{9}$ Hybridity, in the form of methodological variety, tends to increase along with an increase of geographic scale, as partners from different countries and regions make distinct methodological choices that may be required to adapt the centrally led procedures to local contexts and prevailing 'civic epistemologies'.

\section{$<c>2.4$ Topics and themes}

In a world challenged by wicked ecological problems, it is not surprising that environment was the most frequently addressed theme with 9 cases (see also Chapter 22 in this Handbook). Topics covered included, biodiversity, climate, energy, regional sustainability policies, waste, resource efficiency, sustainable consumption and quality of coastal waters. The EU was the next most repeated theme with 6 occurrences. Other themes covered included, health, sustainable transport systems, space, and immigration.

\section{$<c>2.5$ Coordinators and organisers}

The Danish Board of Technology Foundation (DBT) has dominated the organiser field in recent years (see also Chapter 20). Since the WWViews on Global Warming on 2009, DBT has been one of the organising bodies in every transnational and global mini-public, except the AWARE, VOICES and Citizens' debate on space for Europe. Before the DBT rose to prominence in this field, the King Baudouin Foundation (KBF) used to be the central player in the field at the EU level. Other central players include ISINNOVA and Missions Publiques.

All cases studied have involved extensive networks of actors, all with different roles, as reflecting their backgrounds as funders, national and international policy agencies, research institutes, media companies, consultancies, non-governmental civil society organisations, ministries, science museums, technology assessment agencies ${ }^{10}$, and many other types of actors. It is worth noting that The WWViews Alliance remains practically the only network prepared to launch global scale mini-publics.

\section{$<c>2.6$ Number of participants and 'deliberative effort'}

The total number of participants ranged from 26 in RAISE to 8,700 in WWViews on Climate and Energy. There is no clear historical path, except that the number of European wide mini-publics can be counted not in dozens, but in hundreds or thousands of participants, while global processes involve several thousand citizens.

The number of participants is closely linked to the methods. Deliberative polling is an interesting case, as the total number of participants (c. 350) in the two transnational cases (Table 1) was not any higher than in parallel national deliberative polls, where the range of participants has been 200-466. In theory there is no upper limit for the number of participants in deliberative polls, but a practical limitation is that all participants should fit into the same plenary room. There are differing opinions among practitioners about the relative importance of the size of the mini-public and other aspects of recruitment, such as random selection and rigorous sampling techniques (Fishkin and Farrar, 2005; Fishkin 1995; for a discussion on representation in global deliberations, see Rask et al., 2012 and Rask and Worthington, 2015).

There are two reasons, why the majority of transnational mini-publics have convened larger citizen panels involving thousand or more participants. First, most of such processes have selected several simultaneous national citizen panels, rather than a single multinational panel; since an adequate level of demographic variety is requested of each national panel, the number of parallel panels becomes a multiplier of the number of participants. Composing simultaneous national mini-publics vs. one multinational one, also raises the questions, what can actually be called transnational vs. international DDP. Another reason can be that many 
practitioners see large-scale mini-publics as offering greater legitimacy and a more compelling story to communicate to decision-makers (Rask et al., 2012).

Finally, an important observation is that the higher the number of participants, the more impressive is the 'deliberative effort' generated by the mini-public. ${ }^{11}$ By deliberative effort we mean the actual workload, in other words, person years spent in deliberating policy options. The world record is from WWViews on Climate and Energy, where 8,700 person globally spent one full day in deliberating issues of COP climate negotiations, which equals with over 30 person-years of work.

\section{$<c>2.7$ Budgets}

The Budgets of the mini-publics studied varied from $\$ 4.5$ million in the European Citizens Consultation I Wide Views on Sustainable Consumption to $\$ 0.4$ million in CASI. The cost of 'one voice' (total budget divided by the number of participants) varied from \$20,640 in Meeting of Minds to \$240 in WWViews on Climate and Energy. The most expensive bill for facilitating one voice was therefore 86 times more expensive than the cheapest one.

There are many factors that explain the big differences between the budgets. The most important factor is that the cases are very different in function. Some of them are narrow citizen consultations, whereas others are broad research, development and training projects involving extensive communication and training events in many different countries and locations. Second, there are big differences between the methods applied. A major dividing feature is between upstream, explorative, and in-depth oriented deliberations which can be done with small groups that delve into deliberations for several days (for example, RAISE involved six deliberative days), and downstream deliberations, where it is easier to identify and present issues, and relate them to alternative policy options, and where bigger numbers and representativity become more important to legitimise results (for example, WWViews on Climate and Energy involved one deliberation day). ${ }^{12}$ Methodological differences also include different trade-offs between 'scientific quality' and affordability of the process. Deliberative polling, for example, emphasises rigorous selection criteria more than WWViews, which aims to develop processes that are accessible also to countries with more limited budgets. A third explanation for the budgetary differences is a learning curve. The costs of the very first transnational deliberation are higher, as they did pioneering work that has paved the way for later projects.

Notwithstanding, the cost of transnational and global citizen deliberations are so high that they must be launched selectively. There is no one right way to judge what is finally a high or low price for democratic deliberation. In comparison to locally or nationally organised mini-publics, such as professionally organised consensus conferences involving 10-20 citizens, where the cost ranges from US\$70,000 to US\$150,000 (Joss and Durant, 1995), ${ }^{13}$ the per capita cost of transnational mini-publics can be higher or lower. The costs of mini-publics can also be compared to other ways of doing the same job, if available. In a report on Australian mini-publics, Wendy Russell (2017) found out that citizen juries organized in Southern Australia were regarded as more efficient, in both cost and time, compared with typical processes of policy review within a government department. This is an area worthy of further research.

\section{$<b>3$. Emerging trends and impacts}

Measuring the effects of mini-publics to policy making is ordinarily considered difficult for reasons, such as the diffuse nature of the impacts, long time spans involved, as well as under and over determination of the impacts. Despite the difficulties, several evaluation frameworks have been developed. Prominent examples include the 'Public Participation Spectrum' of the International Association of Public Participation (IAP2, 2014) and 'Democracy cube' developed by Professor Archon Fung (2015; see also Goodin and Dryzek, 2006; Rask et al. ,2018). 
It is beyond the scope of this article to engage in a systematic study of the impacts of all transnational minipublics compiled in Table 1. However, based on our observations and in-depth study of some of these processes, we next hypothesise some emerging patterns of impacts.

First, participant learning effects are high. An example is Tomorrow's Europe, in which 362 citizens from across the EU, convened in the European Parliament, in the fall of 2007 to address important social and foreign policy issues facing the Parliament, such as the circumstances in which military force is justified, and the reforms needed to preserve national pension systems, through a deliberative poll. In the case of pensions, for example, participants became significantly more supportive of proposals to increase the retirement age (from $26 \%$ before the deliberation to $40 \%$ after the deliberation) and to make it attractive to work longer before retiring (from $57 \%$ to $70 \%$ ). The number taking the view that current practices would bankrupt the system also increased, from $50 \%$ to $59 \%$ (Tomorrow's Europe, 2007). Results, such as these can provide policy makers with important information about the viability of policy proposals that is not otherwise available. Perhaps reflecting the good conditions for learning that mini-publics provide to the participants, the figures describing levels of satisfaction are regularly high for most mini-publics. In WWViews for Global Warming, for example, 98 per cent of the respondents to the global exit survey were satisfied with the organisation of the event, and 100 per cent of the participants thought that it was beneficial to continue such dialogue processes in the future (Rask et al., 2012).

Second, direct policy impacts are low. None of the cases studied were 'hard-wired' to policy, and several studies have paid attention to the limited policy impacts of large-scale European mini-publics (Boucher, 2009; Boussaguet, and Dehousse, 2008; Rask, 2013). One of the rare examples where direct policy impacts were reported is The Meeting of Minds that contributed to the EC's Green Paper on Mental Health, and fostered the design and implementation of the EU $7^{\text {th }}$ Framework Programme Plan D's European Citizen consultation projects (Irwin 2007; Toulemonde et al. 2009).

Third, the institutional and media impacts of mini-publics are moderate. 'Institutional impacts' includes changes in the political context of deliberations, such as new deliberative competences introduced to the actors and organisations, new networks created and mobilised, new topics introduced in public debates, and scientific citizenship and civic capacities developed. Transnational mini-publics have also sparked broad academic interest.

Institutional impacts also include influences on public debates that take place through traditional and new media (Goodin and Dryzek 2006). Changing the contents of public debates can significantly impact citizens' attitudes and voting behavior, and pressure decision makers to revise their strategies. Fishkin, has suggested that many of the televised pre-election deliberative polls have impacted citizens' voting behavior, for example in the 1999 Australian referendum on whether or not Australia should cease to have a monarch and become a republic (Fishkin, Luskin et al. 2000), and in the 1997 British general election (Fishkin 1995, p.196200). Europolis, the second European-wide deliberative poll was also placed just before European wide elections (Fishkin et al. 2014).

There is suggestive evidence that the larger scale of deliberation results in better publicity. According to an evaluation of the 107 national and local level and six pan-European citizen consultation projects, the media coverage of the national projects was generally quite low, while the largest events including Tomorrow's Europe and European Citizens Consultation I and II attracted considerable attention (Toulemonde et al. 2009; Goldschmidt et al. 2008). Compared to the high expectations, however, the media coverage of transnational mini-publics has often remained disappointingly low. Some potential explanations include, the temporary nature of the media coverage (Toulemonde et al. 2009), difficulty of engaging global or international media companies (Scheinder and Delborne, 2011), and the 'fuzzy' status of mini-publics as compared to more traditional means of gauging public opinion (see also Chapter 3.7 in this Handbook). 


\section{$<b>4$. Discussion}

When looking towards the future of transnational mini-publics and other DDPs, there are four areas that need to be addressed: firstly, the need for this type of innovation, secondly, the impacts of new technologies, and thirdly, resource needs and constraints, and finally, evaluation and methodological development.

In observing the recent challenges of the international political system, one could argue that the heyday of global mini-publics is over. After all, if global agreements are falling apart (for example Brexit, the failure of the Trans-Pacific Partnership, and the US decision to exit the Paris Climate Agreement) and global institutions are suffering a crisis of legitimacy, is there a need for developing transnational democratic deliberations? We argue that addressing the legitimacy crisis facing international institutions is likely to make global DDPs more attractive to many actors. The events of recent years have heightened the need to engage and interact with citizens, also across national borders. We therefore see a continued need for global deliberative mini-publics in the future. The potential for transnational deliberative mini-publics to help democratise current transnational governance systems has not been explored fully.

Technology has impacted on Deliberative Democracy processes and will continue to do so. ICTs and online methods (see Chapter 7 in this Handbook) will add new opportunities for global deliberative mini-publics. ${ }^{14}$ Various technological developments are likely to change the landscape for what is possible in transnational deliberation. For example, Artificial Intelligence is likely to contribute to one of the main challenges for making large scale deliberations with the use of qualitative methods (see Chapter 32), without suffering from 'death by data'. It may be possible in the near future to develop methods that would allow a massive number of qualitative output from mini-publics, making it possible to combine upstream with large-scale methods. The challenge is, though, to make the generation of results sufficiently transparent and implement checks and balances that can guarantee participants' trust, and sense of ownership. Automated translation and interpretation may make multilingual deliberation more feasible and improvements in augmented reality and teleconferencing technologies may make it easier to combine face to face and virtual deliberations. Other emerging trends, such as gamification may tap into different motivations to take part and thus broaden the appeal of deliberative mini publics.

Given the sluggish recovery after the global recession and the continuing public sector budgetary pressures in many countries, it is likely that democratic innovations in global governance will face continued budget constraints. There will be pressures to engage larger numbers at a lower cost. There is a continued challenge to deliver effectively without affecting the quality of the deliberative interaction. Some means to address this challenge are 'distributed dialogues' where the process is designed centrally but local events are organised and held by local groups and volunteers and modern technologies used to make such activities technically feasible. ${ }^{15}$ Another challenge around resources relates to the motivation of funders to sponsor mini-publics. There are basically two kinds of motivation behind funding DDPs: Some funders put more weight on the virtue of the democratic process, whereas others put more emphasis on the results and impacts on political decision making. This is particularly true of funders for environmentally focused mini-publics, as they tend to value results (more environmentally friendly policies) over process (transparent, informed, and inclusive deliberations). The risk of 'sustainability backlash' (such as currently witnessed in the US) increases with the tendency to put environmental results before democratic process.

A recent academic contribution to the understanding of the role of mini-publics and other deliberative processes is the 'deliberative systems' approach (Stevenson and Dryzek, 2014; Parkinson and Mansbridge, 2012; Dryzek, 2010). The deliberative systems approach suggests that we miss the bigger picture if we practice and observe mini-publics as singular events. Instead, practitioners should work actively on several fronts in order to improve the deliberative system, rather than focussing on one off processes to provoke change through the power of example. Academic interest in mini-publics needs to be broadened beyond the study of individual methods and processes toward the gaps and potentials in the broader deliberative system. 
On a parallel note, this broader focus on the deliberative system also challenges us to broaden our understanding of 'policy impact'. As pressure increases for the application of Key Performance Indicators and other instruments for measuring effects of project activities, it is important to develop a broader understanding of the policy impact of DDPs, beyond the crude - and often also unwarranted - request for 'direct' policy impacts in the shape of legislation etc.

Finally, WWViews is currently the only tested method available for global DDPs. It is only a matter of time before more will emerge. The prospects for methodological development are high in this respect. For instance, WWViews has been focusing on downstream decision making, connecting to COPs with identified policy options at hand and a relative clarity of arguments for choosing one over the other. What is currently lacking are methods for transnational upstream deliberations at the global level. Elements for such methods are there (consensus conferences, CIVISTI, etc.) but there is a need for courageous methodological development in order to make them fit the global context with more diverse actors and policy contexts. The challenge is there, and improving the quality and democracy of the international political system is a very good reason to start addressing it. 


\section{References}

Amelung, N. and B. Baumgarten (2017), 'The Transnational Perspective of Political Participation: Linkages and Differences between Social Movement and Public Participation Studies'. Global Society, 31 (1), pp. 3-22. Amelung, Nina (2015), 'Standardizing Heterogeneity: Negotiating Designs for Transnational Citizens Engagement', in Mikko Rask and Richard Worthington (eds), Governing Biodiversity through Democratic Deliberation, London and New York: Routledge, pp. 249-268.

Andersson, Edward, Simon Burall, and Emily Fennel (2010), Talking for a Change: A Distributed Dialogue Approach to Complex Issues (London: Involve)

Asselt Marjolein, B.A.v. and N. Rijkens-Klomp (2002), 'A look in the mirror: reflection on participation in Integrated Assessment from a methodological perspective', Global Environmental Change, 12 (3), pp. 167184.

Bedsted, Bjorn, Soren Gramand Lars Klüver (2012), 'The story of WWViews, in Mikko Rask, Richard Worthington and Minna Lammi (eds), Citizen Participation in Global Environmental Governance, London and New York: Earthscan, pp. 30-41.

Bedsted, Bjorn, Soren Gram, Marie Louise Jørgensen and Lars Klüver (2015), 'WWViews on Biodiversity: new methodological developments and ambitions', in Mikko Rask and Richard Worthington (eds), Governing Biodiversity through Democratic Deliberation, London and New York: Routledge, pp. 27-40.

Beierle, Thomas C. and Jerry Cayford (eds) (2008), Democracy in Practice: Public Participation in Environmental Decisions, Washington, DC: Resources for the Future.

Blue, Gwendolyn, Jennifer Medlock and Edna Einsiedel (2012), 'Representativeness and the Politics of Inclusion: Insights from WWViews Canada', in Mikko Rask, Richard Worthington and Minna Lammi (eds), Citizen Participation in Global Environmental Governance, London and New York: Earthscan, pp. 139-152.

Boucher, Stephen (2009), 'If Citizens Have a Voice, Who's Listening? Lessons from Recent Citizen Consultation Experiments for the European Union', EPIN Working Paper No. 24.

Boussaguet, Laurie and Renaud Dehousse (2008), 'Lay people's Europe: A Critical Assessment of the First EU Citizens' Conferences', European Governance Papers (EUROGOV) No. C-08-02.

Brandstetter, Regina, Martin F. Gajdusek, Alexander Kesselring and Klaus Schuch (2011), 'Evaluation of the FP7 project CIVISTI', Vienna: Centre for Social Innovation.

Decker, Michael and Miltos Ladikas (eds) (2004), Bridges between Science, Society, and Policy, Berlin: Springer-Verlag.

Delli Carpini, M., F. L. Cook, and L. R. Jacobs (2004), 'Public Deliberation, Discursive Participation, and Citizen Engagement', A Review of the Empirical Literature in Annual Review of Political Science, 7 (1), pp. 315-344.

Dietz, Thomas and Paul C. Stern (eds) (2008), Public Participation in Environmental Assessment and Decision Making, Washington DC: The National Academies Press.

Dryzek, J. S. (2016), 'Institutions for the Anthropocene: Governance in a Changing Earth System', British Journal of Political Science, 46 (4), pp. 937-956.

Dryzek, J. and H. Stevenson (2011), 'Global Democracy and Earth System Governance', Ecological Economics, 70 (11), pp. 1865-1874.

Elstub, Stephen and Oliver Escobar (2018) 'A Typology of Democratic Innovations', in Stephen Elstub and Oliver Escobar (eds), Handbook of Democratic Innovation and Governance, Cheltenham: Edward Elgar Publishing.

Einsiedel, E. F., E. Jelsøe and T. Breck (2001), 'Publics at the technology table: The consensus conference in Denmark, Canada, and Australia', Public Understanding of Science, 10 (1), pp. 83-98.

European Commission (2001), 'European Governance: A White Paper, COM (2001) 428', Brussels: Commission of the European Communities.

Felt, U. and M. Fochler (2010), 'Machineries for Making Publics: Inscribing and De-Scribing Publics in Public Engagement', Minerva 48 (3), pp. 319-338.

Fishkin, James S. (1995), The Voice of the People: Public Opinion and Democracy, New Haven and London: Yale University Press.

Fishkin, J. S., R. C. Luskin and R. Jowell (2000). 'Deliberative polling and public consultation', Parliamentary affairs, 53 (4), pp. 657-666. 
Fishkin, James and Cynthia Farrar (2005), 'Deliberative Polling: From Experiment to Community Resource', in John Gastil, and Peter Levine (eds), The Deliberative Democracy Handbook: Strategies for Effective Civic Engagement in the $21^{\text {st }}$ Century, San Francisco: Jossey-Bass, pp. 68-79.

Fishkin, James S. (2009), When the People Speak. Deliberative Democracy \& Public Consultations, New York: Oxford University Press.

Fishkin, J. S., R. C. Luskin, A. Siu (2014), 'Europolis and the European public sphere: Empirical explorations of a counterfactual ideal', European Union Politics, 15 (3) pp. 328-351.

Fung, A. (2015). Putting the public back into governance: The challenges of citizen participation and its future. Public Administration Review, 75(4), 513-522.

Geurts, Jac L., and Igor Mayer (1996), 'Methods for participatory policy analysis: Towards a conceptual model for research and development'. Tilburg, Netherlands: Work and Organization Research Centre.

Goldschmidt, Rudiger, Ortwin Renn and Sonja Köppel (2008), 'European Citizens' Consultations Project, Final Evaluation Report '. Stuttgart: Institut für Sozialwissenschaften.

Goldschmidt, Rudiger and Otwin Renn (2006), 'Meeting of Minds - European Citizens' Deliberation on Brain Sciences', Stuttgart: University of Stuttgart.

Goodin, R. E. and J. S. Dryzek (2006), 'Deliberative Impacts: The Macro-Political Uptake of Mini-Publics', Politics \& Society, 23 (2), pp. 219-244.

Grönlund, Kimmo, Andre Bächtiger and Maija Setälä (2014), Deliberative Mini-Publics. Involving Citizens in the Democratic Process, Colchester, UK: ECPR Press.

Elliott, Janice, Sara Heesterbeek, Carolyn J. Lukensmeyer and Nikki Slocum (2005), 'Planning Cell', in Stef Steyaert and Herve Lisoir (eds), Participatory Methods Toolkit. A practitioner's manual, King Baudouin Foundation and the Flemish Institute for Science and Technology Assessment, pp. 151-162.

IAP2 (2014), IAP2's Public Participation Spectrum, International Association for Public Participation, accessed [insert

date]

c.ymcdn.com/sites/www.iap2.org/resource/resmgr/foundations_course/IAP2_P2_Spectrum_FINAL.pdf.

Irwin, A. (2001), 'Constructing the Scientific Citizen: Science and Democracy in the Biosciences', Public Understanding of Science, 10 (1) pp. 1-18.

Jasanoff, Sheila (2005), Designs on nature: Science and democracy in Europe and the United States, Princeton and Oxford: Princeton University Press.

Joss, Simon and Sergio Bellucci (eds) (2002), Participatory Technology Assessment. European Perspectives, London: Centre for Study of Democracy.

Joss, Simon and John Durant (eds) (1995), Public participation in science: The role of consensus conferences in Europe, London: NMSI Trading Ltd.

Jungk, Robert, and Norbert Muellert (eds) (1987), Future workshops. How to create desirable futures, London: Institute for Social Innovations.

Kahane, D., K. Lopston, J. Herriman and M. Hardy (2013), Stakeholder and Citizen Roles in public deliberation, Journal of Public Deliberation, 9 (2), pp. 1-35.

Kies, Ralph and Patrizia Nanz (eds) (2013), Is Europe listening to us? Successes and failures of EU citizen consultation, Farnham, England: Ashgate.

Klinke, A. (2009), 'Deliberative Transnationalism - Transnational Governance', Public Participation and Expert Deliberation in Forest Policy and Economics, 11 (5-6), pp. 348-356.

Levidow, L. (1998), 'Democratizing Technology - Or Technologizing Democracy? Regulating Agricultural Biotechnology in Europe', Technology in Society, 20 (2), pp. 211-226.

Lukensmeyer, Carolyn J., Joe Goldman and Steven Brigham (2005), 'A town meeting for the twenty-first century', in John Gastil, and Peter Levine (eds), The Deliberative Democracy Handbook: Strategies for Effective Civic Engagement in the $21^{\text {st }}$ Century, San Francisco: Jossey-Bass, pp. 154-163.

Tomorrow's Europe (2007), 'Majority of EU citizens accept the idea of retiring later', accessed 16 June 2017 at http://www2.aueb.gr/statistical-institute/EU-Tomorrow/press-release-18oc07.pdf.

OECD (2001), Citizens as Partners. Information, Consultation and Public Participation in Policy-making, Paris: OECD Publishing. 
Parkinson, John, and Jane Mansbridge (eds) (2012), Deliberative Systems: Deliberative Democracy at the Large Scale, Cambridge: Cambridge University Press.

Rask, Mikki, Saule Maciukaite-Zviniene, Loreta Tauginienè, VyTautas Dikcius, Kaisa Matschoss, Timo Aarrevaara and Luciano d'Andrea (2018), Public Engagement, Science and Society: Tools for Dynamic and Responsible Governance of Research and Innovation, Routledge, London and New York.

Rask, Mikko and Richard Worthington (2012), 'Toward a New Concept of Global Governance' in Mikko Rask, Richard Worthington and Minna Lammi (eds), Citizen Participation in Global Environmental Governance, London and New York: Earthscan, pp. 3-29.

Rask, Mikko, Richard Worthington, and Minna Lammi (eds) (2012b), Citizen Participation in Global Environmental Governance, London and New York: Earthscan.

Rask, M (2013), 'The tragedy of citizen deliberation - two cases of participatory technology assessment', Technology Analysis and Strategic Management, 25 (1), pp. 39-55.

Rask, Mikko, and Richard Worthington (eds) (2015), Governing Biodiversity through Democratic Deliberation, New York and London: Routledge.

Rask, Mikko (2009), Expansion of Expertise in the Governance of Science and Technology, Köln, Germany: Lambert Academic Publishing.

Renn, Ortwin (2008), Risk Governance: Coping with Uncertainty in a Complex World, London: Earthscan.

Russell, Wendy (2017), 'The Macro-Impacts of Citizen Deliberation Processes', Final Research Report, newDemocracy Foundation, Australia.

Sclove, Richard (2010), Reinventing technology assessment. A $21^{\text {st }}$ century model. Washington, DC: Woodrow Wilson International Center for Scholars.

Spada, P., and Ryan, M. (2017), The failure to examine failures in democratic innovations, Political Science \& Politics, 50(3), 772-778.

Toulemonde, Jaques, Thomas Delahais, Francis (2009), 'Evaluation of the Plan D/ Debate Europe citizen consultation projects', Brussels: European Commission.

Voß, J. P., and N. Amelung (2016), 'Innovating public participation methods: Technoscientization and reflexive engagement', Social Studies of Science, 46 (5), pp. 749-772.

Warburton, Dianne (2011), Evaluation of Sciencewise-ERC. Final Report, May 2011', accessed 16 June 2017 at www.sciencewise-erc.org.uk/cms/sciencewise-evaluation/.

Worthington, Richard and Rose Egelhoff (2015), 'The variegated landscape of biodiversity policy ', in Mikko Rask and Richard Worthington (eds), Governing Biodiversity through Democratic Deliberation, London and New York: Routledge, pp. 43-65.

Worthington, Richard, Mikko Rask and Birgit Jæger (2012), 'Deliberative Global Governance: Next Steps in an Emerging Practice', in Mikko Rask, Richard Worthington, and Minna Lammi (eds), Citizen Participation in Global Environmental Governance, London and New York: Earthscan, pp. 263-286.

Young, I. M. (1989), 'Polity and group difference: A critique of the ideal of universal citizenship'. Ethics, 99 (2), pp. 250-274. 


\section{Acknowledgements}

The research for this paper has been supported by the Public Innovations for Horizon 2020 (PE2020) project, grant agreement number 611826 .

\footnotetext{
${ }^{1}$ University of Helsinki

${ }^{2}$ Danish Board of Technology foundation

${ }^{3}$ Involve

${ }^{4}$ University of Helsinki
}

${ }^{5}$ We gratefully acknowledge that this paper was inspired by an unpublished manuscript "The emergence of large-scale deliberative democratic processes" by Jade Herriman, Mikko Rask, Chris Riedy and Richard Worthington from the year 2014.

${ }^{6}$ Examples of internationalization of mini-publics include the 'travel' of the consensus conference methods from the USA to Denmark and other European and finally to non-European countries (e.g. Einsiedel et al., 2001, p. 8183; Sclove, 2010, p. 43), while the adaptation of the deliberative approach in Confucian, Islamic and other non-Western cultures (e.g. Dryzek, 2009, p. 1383, 1396) represents a more general travel of ideas between countries and cultures.

${ }^{7}$ Indeed, some of the core processes in citizen participation have been privatized, for instance, Citizens Jury ${ }^{\circledR}$, Deliberative Poll ${ }^{\circledR}$ and 21 st Century Town Meeting ${ }^{\mathrm{TM}}$ have all been trademarked or registered.

${ }^{8}$ EC, accessed 28 June 2017 at http://ec.europa.eu/programmes/horizon2020/en/h2020-section/responsibleresearch-innovation.

${ }^{9}$ Hybridity was also among the key characteristics of innovative public engagement procedures studied in a recent international study (Rask et al., 2018).

10 Many of the organizers, including DBT, are technology assessment agencies affiliated to the European Parliamentary Technology Assessment (EPTA) network.

11 Another factor contributing to the deliberative effort is the number of days spent in deliberations. In Consensus conference and Civisti methods, for example, participating citizens normally gather together over two or three weekends, which increases deliberative effort while the number of participants remain the same.

${ }^{12}$ For this reason, the cost of 'deliberative effort' should be considered as relevant cost indicator as the cost of 'one voice', since the deliberative effort can be highly different not only due to the number of participants but also due to the number of days that the participants spend in deliberating.

13 Aspiri K. (2010), Consensus Conference, accessed 28 June 2017 at http://participedia.net/en/methods/consensus-conference.

${ }^{14}$ For example, DBT has developed an online public engagement platform, EngageSuite that has already been applied in a few European projects.

${ }^{15}$ Andersson, E., Burall, S., \& Fennel, E. (2010), Talking for a Change: A Distributed Dialogue Approach to Complex Issues (London : Involve) 